\title{
Resident mysids: secondary production, consumption, and trophic role in a coral reef lagoon
}

\author{
J. H. Carleton*, A. D. McKinnon \\ Australian Institute of Marine Science, PMB No. 3, Townsville Mail Centre, Queensland 4810, Australia
}

\begin{abstract}
Annual patterns in standing stock, production, and consumption of mysids on the lagoon floor at Davies Reef on the Great Barrier Reef mirrored the distribution and abundance of the more ubiquitous species - Erythrops nana, Doxomysis littoralis, Anisomysis pelewensis, and Prionomysis stenolepis. Mysids were most abundant during austral spring and early summer (September to December), which coincided with the seasonal maximum in lagoon deposition rates of detritus rather than the peak time of primary production (February to May). Secondary production, excluding the relatively large schooling species A. australis, ranged between $0.2 \mathrm{mg} \mathrm{C} \mathrm{m}^{-2} \mathrm{~d}^{-1}$ in May and $6.5 \mathrm{mg}$ $\mathrm{C} \mathrm{m}^{-2} \mathrm{~d}^{-1}$ in October and was similar to estimates for other tropical or sub-tropical species, but was either comparable to or very much lower than estimates for temperate species. However, daily production:biomass $(P: B)$ ratios for lagoon mysids were extremely high compared with cold-water species. Diurnal feeding ranged between 0.5 and $16.3 \mathrm{mg} \mathrm{C} \mathrm{m}^{-2} \mathrm{~d}^{-1}$, and accounted for approximately 1 to $21 \%$ of detritus deposition at shallow sites within the lagoon. The hyperbenthic mysid community consumed less detritus than either the sediment invertebrate infaunal or bacterial communities, but similar quantities to the water column zooplankton community. As large areas of Indo-Pacific coral reefs and atolls are either sandy lagoons or back-reef slopes - appropriate habitat for these relatively large, abundant, reef-resident zooplankters - the role of mysids within coral reef ecosystems through the remineralization of detritus must be substantial.
\end{abstract}

KEY WORDS: Resident mysids · Respiration · Secondary productivity $\cdot$ Coral reef lagoon Resale or republication not permitted without written consent of the publisher

\section{INTRODUCTION}

Mysids constitute an integral part of the hyperbenthos in many littoral, coastal, deep water, and freshwater habitats (Mauchline 1980). On coral reefs they form a highly visible component of the resident planktonic community (Emery 1968), and function as macrophages, carnivores, and detritivores (Gottfried \& Roman 1983, Mullin \& Roman 1986). Within coral reef lagoons mysids are characteristic of the resident hyperbenthic community (Carleton \& Hamner 2007, this volume), varying in abundance seasonally from 110 ind. $\mathrm{m}^{-3}$ in February to 790 ind. $\mathrm{m}^{-3}$ in October, with schooling species occurring at local densities in excess of 500000 ind. $\mathrm{m}^{-3}$ (Carleton \& Hamner 1989). As is the case with many coastal and littoral mysids (Mauchline 1980), coral reef mysids most likely function as detritivores, remineralizing a substantial portion of lagoon organic detritus (Carleton \& Hamner 1989).
Coral reef lagoons are zones of net heterotrophy requiring input of detritus from adjacent areas of high primary production (Wilkinson 1987, Alongi 1988). Attempts to model the resulting complex of secondary, detritus-based food webs have concentrated on processes within the water column (Roman et al. 1990) and within the sediments (Alongi 1986, Riddle et al. 1990, Hansen et al. 1992), generally ignoring the rich diversity of animals that blanket the lagoon floor. Members of the lagoon hyperbenthos in general, and mysids in particular, are not captured effectively by conventional benthic or pelagic devices (Carleton \& Hamner 1987) and are under-represented in core, grab, and emergence trap samples. These sampling deficiencies have resulted in a trivialization of the importance of this suite of animals in coral reef ecosystems and the exclusion of their secondary production estimates from existing trophic models (Wilkinson 1987). 
In the present study we established the role of hyperbenthic mysids as detritivores and determined, for the first time, the functional relationships between length, chemical composition, and respiration rates for this unique reef-resident community. By applying weightspecific respiration rates to abundance data, we derived estimates of secondary production and feeding throughout the year and calculated the proportion of organic matter on the lagoon floor consumed by the entire mysid community. Our estimates must be considered as conservative first approximations, but are nonetheless essential components for the development of complete, realistic trophodynamic models of coral reef lagoon ecosystems.

\section{MATERIALS AND METHODS}

Sampling. Three replicate diurnal samples of mysids were collected every 6 wk between July 1980 and May 1981 (July, September, October, and December 1980; February, March, and May 1981; $\mathrm{n}=21$ ) from depths between 8 and $11 \mathrm{~m}$ on the lagoon floor at Davies Reef, Great Barrier Reef (see Fig. 1 in Carlton \& Hamner 2007). The benthic sampling device was specifically designed to capture highly motile animals within a $10 \mathrm{~m}^{2}$ area up to $1 \mathrm{~m}$ above the sediment (Carleton \& Hamner 1987). Replicate catches were taken sequentially with 3 separate samplers placed 4 to $6 \mathrm{~m}$ apart. In the laboratory mysids were separated from any sand that may have been present by repeatedly swirling the samples and decanting the supernatant through a series of sieves until the wash was free of plankton (Birkett \& McIntyre 1971). Large or rare organisms were removed and counted. Subsamples ranging from $1 / 4$ to $1 / 32$ of the total catch were extracted with a Folsom splitter (Van Guelpen et al. 1982) and examined for composition and abundance under a stereoscopic microscope. Mysids from a single complete replicate set $(n=7)$ were measured to the nearest $0.01 \mathrm{~mm}$ for total body length and classified as juvenile, immature male, immature female, mature male, or mature female (Mauchline 1980), with mature females noted as spent or carrying larvae. The age-class and lengthfrequency distributions thus derived were applied to the numerical data from the other 2 replicate sets. Information on mysid community structure, abundance, spatial/temporal distributions, and aspects of their behavior is given elsewhere (Carleton \& Hamner 1989).

Estimates of secondary production and food requirements. Potential secondary production and consumption were estimated by budgetary methods (Omori \& Ikeda 1984) as other approaches, for various reasons, were considered inappropriate. Estimates of secondary production (growth) from cohort analysis of length data were not possible as the mysids in Davies Reef lagoon appear to breed continuously throughout the year (Carleton \& Hamner 1989) and the period between collections (approximately $6 \mathrm{wk}$ ) was too long to detect any shifts in the length-frequency distribution of various age classes. Application of the sizefrequency (Hynes) method for secondary production was not possible as not enough vital life-history information was available, specifically on cohort production intervals, to meet the prerequisites for this method (Iversen \& Dall 1989), and the presence of detrital material, sand grains, and other foreign material in samples precluded the use of total catch biomass and abundance data to calculate community production from the frequency distribution of average zooplankton weights (Ikeda \& Motoda 1978, Ikeda et al. 1982).

Mysid respiration. Respiration experiments were carried out on board RV 'Lady Basten', moored in the lagoon at Davies Reef during December 2001. Fresh mysids were collected from the study site (see Fig. 1 in Carlton \& Hamner 2007) each morning and most afternoons by divers using hand nets $(15 \times 15 \mathrm{~cm})$; large, clear-plastic scoops (15 l); or by swimming a $0.5 \mathrm{~m}$ diameter, $150 \mu \mathrm{m}$ mesh plankton net through schools or close to the lagoon floor. Upon capture, mysids were taken to the surface, transferred to shaded 201 buckets filled with lagoon water, and immediately returned to the research vessel. Respiration chambers were filled with water from the study site, and groups of similarsized mysids, usually from the same school, were gently introduced to a number of chambers. The chambers were clear glass jars (1042 ml) with airtight screw caps incorporating calibrated YSI Model 600 dissolved oxygen/temperature probes. Efficient mixing was maintained by a magnetic stirrer bar in a compartment at the bottom of each jar separated from the main chamber by $1000 \mu \mathrm{m}$ nylon mesh. Stir rate was adjusted so as to allow animals to easily remain stationary. The jars were placed in a water bath maintained at ambient lagoon temperature $\left(\bar{x}=28.8^{\circ} \mathrm{C}\right)$, and oxygen content was recorded every $5 \mathrm{~min}$ after allowing the oxygen electrodes to equilibrate. In most experiments there were 3 treatment chambers containing mysids and a control chamber containing only water. Respiration measurements varied between 1.8 and $3.6 \mathrm{~h}$, and oxygen saturation never dropped below $77 \%$. Respiration rates were measured in the morning $(n=12)$, afternoon (8), and evening (6). At the end of each experiment, animals were fixed with $10 \%$ formaldehyde/filtered seawater for later determination of species composition, age-class composition, and total body lengths.

Gut contents and chemical composition. Specimens were collected from the study site for gut analysis and for carbon/nitrogen composition. Individuals for chem- 
ical composition were identified, sexed, age-classified, measured, wrapped in pre-ashed aluminum foil $\left(450^{\circ} \mathrm{C}\right.$ for $12 \mathrm{~h}$ ), and frozen. Total carbon and nitrogen was determined for individual specimens by high-temperature combustion using an ANTEK 9000NS analyzer, with a Rosemount Analytical Model 880 NDIR detector mounted in-line for carbon analysis. EDTA (32.2\% C, $7.52 \%$ N) was used as a standard.

Calculations. Secondary production $(P)$, including growth, reproduction, and molting, and food requirements $(F)$ can be calculated from respiration measurements $(R)$ if estimates are available for any 2 of the following parameters: assimilation efficiency $(A)$, gross growth efficiency $\left(K_{1}\right)$, or net growth efficiency $\left(K_{2}\right)$ (Omori \& Ikeda 1984). The algebraic relationships among these parameters are as follows:

$$
P=\frac{K_{2} R}{100-K_{2}}=\frac{K_{1} R}{A-K_{1}}
$$

and

$$
F=\frac{100 R}{A\left(100-K_{2}\right) / 100}=\frac{K_{1} R}{A-K_{1}}
$$

For mysids, estimates of assimilation efficiency vary with species, habitat, and diet. Clutter \& Theilacker (1971) obtained an assimilation efficiency of $90 \%$ based on the uptake of $\mathrm{C}^{14}$ labeled phytoplankton by a neritic species; Lasenby \& Langford (1973) obtained values of 85 and $82 \%$ for Mysis relicta when fed on Daphnia pulex and chironomid larvae, respectively; and Toda et al. (1987) obtained a range from 15 to $60 \%$ for Neomysis intermedia fed on Daphnia sp., rotifers, and cladocerans. Toda et al. (1987) also calculated a broad range of $K_{2}$ values ( 25 to $70 \%$ ) that encompassed the range (43 to $57 \%$ ) determined by Shushkina (1972) for the omnivorous species Neomysis mirabilis and the range (32 to $43 \%$ ) obtained by Clutter \& Theilacker (1971). Morioka et al. (1987) applied an assimilation value of $80 \%, K_{1}$ value of $40 \%$, and a $K_{2}$ value of $50 \%$ to a mixed community of hyperbenthic mysids that contained Anisomysis pelewensis. Since this species is important in Davies Reef lagoon, the same values were utilized in the present study. To convert oxygen consumption rate to carbon units a respiratory quotient (RQ) value of 0.97 was considered appropriate as marine zooplankton are primarily ammonotelic (Omori \& Ikeda 1984).

Secondary production and consumption for the entire mysid community was estimated for each sampling period. For each replicate sample, mysid lengths were converted to body mass in carbon units $(\mu \mathrm{g})$ then to oxygen consumption rates $\left(\mu \mathrm{h}^{-1}\right)$ using the log-linear relationships derived from chemical composition analyses and from respiration experiments. Respiration rates were corrected for the effect of changes in habitat temperature using a $Q_{10}$ value of 1.824 , an appropriate value when the regression equation for oxygen uptake is derived from body mass data measured in carbon units (Ikeda 1985), before conversion to carbon equivalents $\left(\mu \mathrm{g} \mathrm{h}^{-1}\right)$ using an $\mathrm{RQ}$ value of 0.97 (Omori \& Ikeda 1984). Productivity and feeding were then calculated from the above equations using the corrected and converted respiration rates and integrated over each replicate sample for all mysids before standardizing to a unit measure. As the benthic sampler effectively captured animals up to $1 \mathrm{~m}$ above the lagoon floor, productivity and feeding can be expressed as either mg $\mathrm{C} \mathrm{m}^{-2} \mathrm{~d}^{-1}$ or $\mathrm{mg} \mathrm{C} \mathrm{m} \mathrm{m}^{-3} \mathrm{~d}^{-1}$. In summary, mean secondary production for all mysids was estimated for each sample using the following formula:

$P=\left[\sum_{i=1}^{\text {No. mysids }} K_{1}\left(\left\{\frac{k_{1}}{\exp \left[\frac{\ln Q_{10}}{10}\left(t_{1}-t_{2}\right)\right]}\right\} \operatorname{RQ}\left\{\frac{12}{22.4}\right\}\right)\left(\mathrm{A}-K_{1}\right)^{-1}\right] 0.0024$

where $K_{1}$ is gross growth efficiency of $40 \%$ (Morioka et al. 1987), $k_{1}$ is respiration rate $\left(\mu \mathrm{h}^{-1}\right)$ calculated from the log-linear relationships derived from chemical composition analyses and respiration experiments, $Q_{10}$ is 1.824 (Ikeda 1985), $t_{1}$ is mean temperature during $\mathrm{O}_{2}$ consumption experiments $\left(28.8^{\circ} \mathrm{C}\right), t_{2}$ is mean monthly habitat temperature (Fig. 1), RQ is 0.97 (Omori \& Ikeda 1984), 12/22.4 is the weight of carbon in $1 \mathrm{~mol}$ of carbon dioxide, $\mathrm{A}$ is assimilation efficiency of $80 \%$ (Morioka et al. 1987), and $2.4 \times 10^{-3}$ is a standardization constant ( $\mathrm{mg} \mathrm{C} \mathrm{d} \mathrm{d}^{-1}$ ). Secondary consumption was 2.5 times $P$, and mean monthly temperatures were calculated from 5 consecutive years of data (1996 to 2000) recorded every $30 \mathrm{~min}$ by an Omega interchangeable thermistor placed $1 \mathrm{~m}$ below the low tide mark in Davies Reef lagoon (Fig. 1).

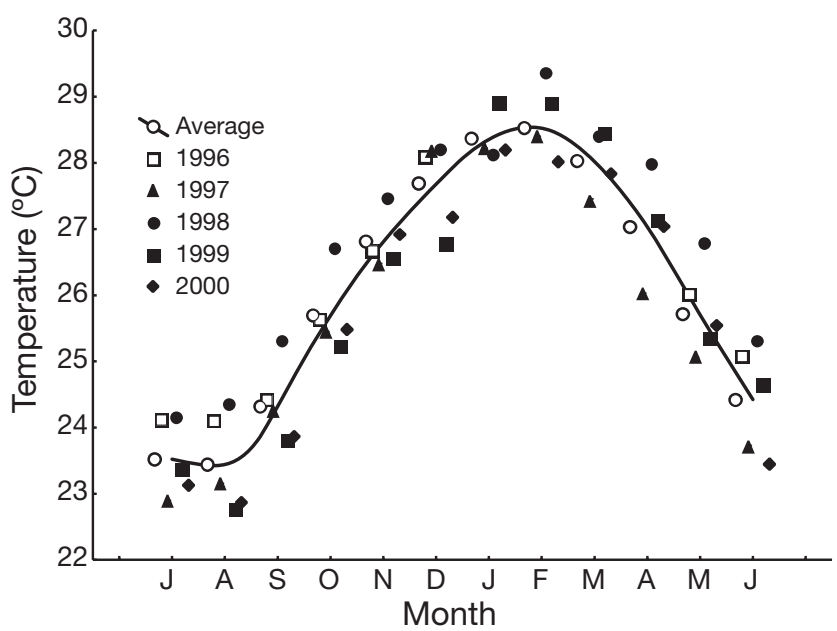

Fig. 1. Mean monthly temperature in Davies Reef lagoon from 1996 to 2000 


\section{RESULTS}

\section{Gut contents and chemical composition}

The majority ( $>90 \%$ ) of specimens with full guts (Anisomysis lamellicauda $\mathrm{n}=40$, Prionomysis stenolepis $\mathrm{n}=13$, Erythrops nana $\mathrm{n}=12, A$. pelewensis $\mathrm{n}=$ 8 , and Doxomysis littoralis $\mathrm{n}=5$ ) contained amorphous material in the cardiac region of their alimentary canals. The guts of some E. nana also contained sand grains, while a few $P$. stenolepis contained pieces of harpacticoid copepods and fish eggs in addition to detritus. The size range (1.51 to $6.88 \mathrm{~mm}$ ) of mysids analyzed for chemical composition encompassed the length of $>80 \%$ of mysids captured on the lagoon floor at Davies Reef and equated to a broad range in total carbon (6.59 to $249.99 \mu \mathrm{g})$ and nitrogen (1.43 to $63.80 \mu \mathrm{g})$. There were too few individuals of A. pelewensis analyzed to formulate any significant regressions. A. lamellicauda had significant relationships for both carbon and nitrogen content in mature males and juveniles, but only when data from both species were combined in a single analysis did significant regressions exist for all age classes (Fig. 2). Regressions of carbon and nitrogen on body length for mature females differed significantly from other classes $(p<$ $0.05,1$-way ANCOVA), because of greater mass per unit length in $A$. pelewensis females.

\section{Respiration}

The majority of respiration experiments (23 of 26) were conducted on Anisomysis lamellicauda (Table 1). A single experiment contained only A. pelewensis and 2 contained a mixture of A. lamellicauda and $A$. pelewensis. The size range of experimental mysids (1.32 to $6.66 \mathrm{~mm}$ ) was similar to those analyzed for carbon and nitrogen content, and spacing within respiration chambers, both in terms of distance (cm) and body lengths, did not differ significantly ( $p>0.05,1$-way ANOVA) from those recorded in situ by Carleton \& Hamner (1989). Three experiments had exceptionally high $\mathrm{O}_{2}$ consumption rates, 2 of which (R3e3 and R3e4; Table 1) were noted as having detritus present in the treatment chambers and not the control. These exceptional values were excluded from any subsequent analyses. Mean $\mathrm{O}_{2}$ consumption rates $\left(\mu \mathrm{l}\right.$ mysid $^{-1} \mathrm{~h}^{-1}$ ) were significantly higher during morning experimental runs than those of the afternoon and evening ( $p<0.05$, Kruskal-Wallis test). The majority of individuals collected in the morning had full guts, while the guts of those collected in the afternoon were mostly empty. This pattern of feeding has been noted in deep-water hyperbenthic mysids

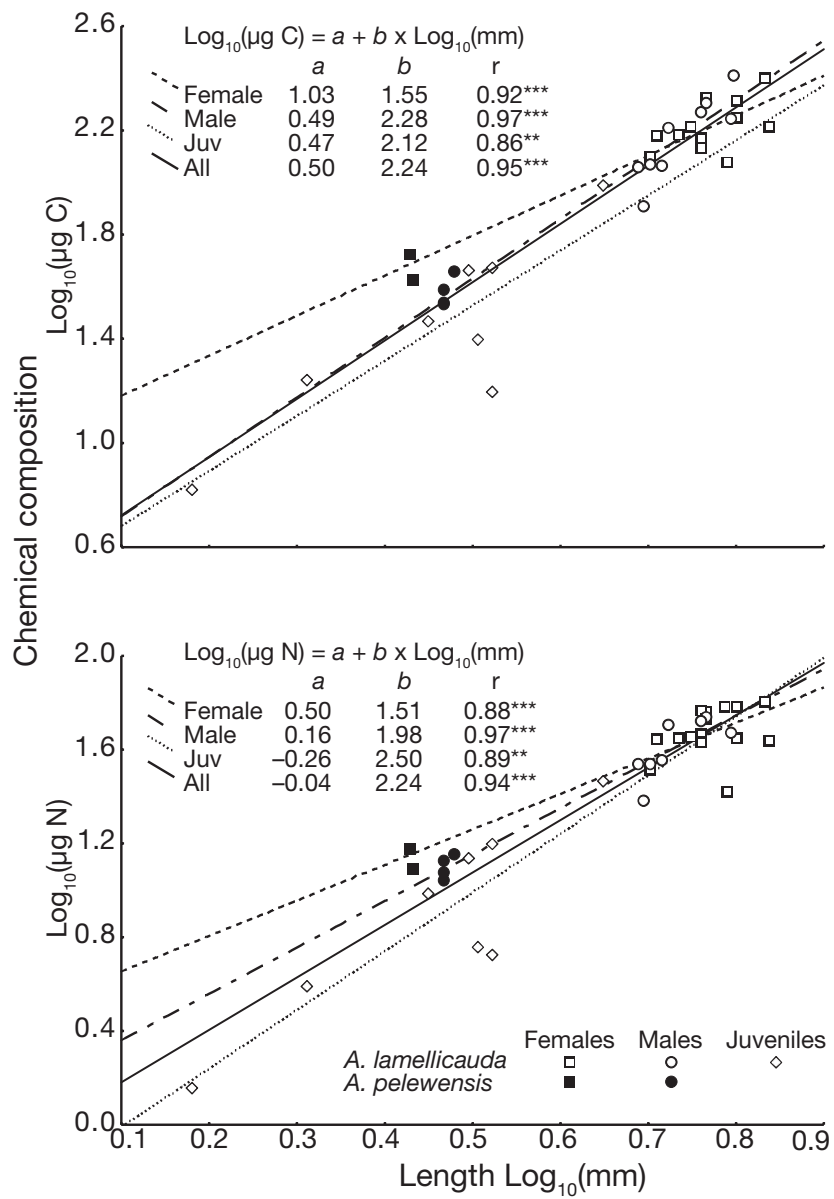

Fig. 2. Log-linear relationships between chemical composition and length for mysids. $* * p<0.01, * * * p<0.001$

(Cartes \& Maynou 2001). Although mysids in Davies Reef lagoon appear to have a morning feeding peak, the differing rates of $\mathrm{O}_{2}$ consumption are not likely due to changes in metabolic activity alone, as, by chance, experimental mysids in morning experiments had a significantly greater mean body mass than those in afternoon and evening experiments $(p<0.05$, Kruskal-Wallis test). The log-linear regressions of oxygen consumption rates on body mass expressed as carbon $\left(\log _{10}\left[\mu l \mathrm{O}_{2}\right.\right.$ mysid $\left.^{-1} \mathrm{~h}^{-1}\right]=-1.0632+0.7388 \times$ $\log _{10}\left[\mu \mathrm{g} \mathrm{C}\right.$ mysid $\left.\left.^{-1}\right]\right)$ and nitrogen $\left(\log _{10}\left[\mu l \mathrm{O}_{2}\right.\right.$ mysid $^{-1}$ $\left.\mathrm{h}^{-1}\right]=-0.6828+0.7524 \times \log _{10}\left[\mu \mathrm{g} \mathrm{N}\right.$ mysid $\left.\left.^{-1}\right]\right)$ were highly significant $(p<0.001)$. These relationships were determined from the values listed in Table 1, with the exception of the 3 outliers (R3e3, R3e4, and $\mathrm{R} 7 \mathrm{e} 3$ ). Carbon and nitrogen values in Table 1 were calculated from age-class specific regressions (mature female, mature male, and juvenile) derived from combined species data (Fig. 2). Content of immature individuals was determined from the regression for all classes combined. 
Table 1. Summary of mean values $( \pm \mathrm{SD})$ from respiration experiments. Spacing: nearest neighbour

\begin{tabular}{|c|c|c|c|c|c|c|c|c|c|c|}
\hline \multirow[t]{2}{*}{ Species } & \multirow[t]{2}{*}{ Ratio } & \multirow[t]{2}{*}{ Code } & \multirow[t]{2}{*}{ Time } & \multicolumn{2}{|c|}{ — Mysids — } & \multicolumn{2}{|c|}{ - Spacing - } & \multicolumn{3}{|c|}{ - Per individual mysid } \\
\hline & & & & $\mathrm{n}$ & $\begin{array}{l}\text { Length } \\
(\mathrm{mm})\end{array}$ & $(\mathrm{cm})$ & $\begin{array}{l}\text { (body } \\
\text { lengths) }\end{array}$ & $C(\mu g)$ & $N(\mu g)$ & $\begin{array}{c}\mathrm{O}_{2} \\
\left(\mu \mathrm{l} \mathrm{h} \mathrm{h}^{-1}\right)\end{array}$ \\
\hline \multirow[t]{18}{*}{ Anisomysis lamellicauda } & & R3e3 & 2.00 & 11 & $5.4 \pm 0.29$ & 5.4 & 10.1 & $143.7 \pm 11.99$ & $40.8 \pm 3.34$ & $14.45^{\mathrm{a}}$ \\
\hline & & R3e4 & 1.83 & 13 & $4.7 \pm 0.67$ & 5.1 & 10.9 & $114.6 \pm 33.12$ & $32.8 \pm 9.22$ & $12.79^{a}$ \\
\hline & & $\mathrm{R} 4 \mathrm{e} 3$ & 2.08 & 25 & $4.7 \pm 0.70$ & 4.1 & 8.81 & $109.17 \pm 4.69$ & $31.2 \pm 10.16$ & 1.95 \\
\hline & & $\mathrm{R} 4 \mathrm{e} 4$ & 2.08 & 20 & $4.7 \pm 0.93$ & 4.5 & 9.5 & $105.1 \pm 46.97$ & $30.1 \pm 13.10$ & 1.94 \\
\hline & & R4e5 & 1.92 & 15 & $5.0 \pm 0.51$ & 4.9 & 9.9 & $121.3 \pm 28.90$ & $34.6 \pm 7.89$ & 2.80 \\
\hline & & R5e3 & 3.33 & 14 & $5.3 \pm 0.30$ & 5.0 & 9.5 & $137.9 \pm 15.11$ & $39.2 \pm 4.08$ & 4.64 \\
\hline & & $\mathrm{R} 5 \mathrm{e} 4$ & 3.50 & 54 & $5.3 \pm 0.34$ & 3.2 & 6.0 & $139.2 \pm 18.63$ & $39.5 \pm 4.88$ & 2.43 \\
\hline & & R7e3 & 2.25 & 17 & $5.4 \pm 0.32$ & 4.7 & 8.7 & $143.2 \pm 14.67$ & $40.7 \pm 3.95$ & $10.66^{\mathrm{a}}$ \\
\hline & & $\mathrm{R} 7 \mathrm{e} 4$ & 2.25 & 49 & $5.0 \pm 0.55$ & 3.3 & 6.6 & $126.0 \pm 29.87$ & $35.9 \pm 8.16$ & 1.98 \\
\hline & & R7e5 & 2.25 & 71 & $4.9 \pm 0.63$ & 2.9 & 5.9 & $121.9 \pm 33.39$ & $34.8 \pm 9.15$ & 3.31 \\
\hline & & R8e5 & 2.83 & 18 & $5.2 \pm 0.51$ & 4.6 & 8.9 & $135.5 \pm 26.66$ & $38.5 \pm 7.26$ & 2.98 \\
\hline & & R9e4 & 2.80 & 34 & $3.7 \pm 0.71$ & 3.7 & 10.2 & $52.4 \pm 28.63$ & $15.7 \pm 8.39$ & 1.77 \\
\hline & & R10e3 & 2.50 & 27 & $5.4 \pm 0.32$ & 4.0 & 7.4 & $144.8 \pm 14.76$ & $41.1 \pm 4.05$ & 3.99 \\
\hline & & $\mathrm{R} 10 \mathrm{e} 4$ & 2.50 & 28 & $5.3 \pm 0.44$ & 4.0 & 7.5 & $138.6 \pm 22.34$ & $39.4 \pm 5.91$ & 2.75 \\
\hline & & R10e5 & 2.50 & 26 & $5.3 \pm 0.51$ & 4.1 & 7.7 & $137.9 \pm 28.49$ & $39.4 \pm 7.57$ & 4.60 \\
\hline & & R11e2 & 2.08 & 40 & $5.1 \pm 0.80$ & 3.5 & 7.0 & $124.7 \pm 46.74$ & $35.6 \pm 12.32$ & 3.14 \\
\hline & & R12e3 & 2.00 & 25 & $4.3 \pm 0.80$ & 4.1 & 9.6 & $87.7 \pm 37.79$ & $25.3 \pm 10.49$ & 3.92 \\
\hline & & R12e4 & 1.83 & 21 & $4.6 \pm 0.79$ & 4.4 & 9.5 & $100.7 \pm 43.83$ & $29.0 \pm 11.92$ & 2.21 \\
\hline A. pelewensis & & R6e3 & 2.25 & 69 & $2.7 \pm 0.19$ & 2.9 & 10.8 & $42.1 \pm 9.89$ & $12.9 \pm 2.19$ & 0.67 \\
\hline A. lamellicauda:A. incisa & $39: 1$ & R5e5 & 3.58 & 40 & $5.2 \pm 0.60$ & 3.5 & 6.8 & $135.4 \pm 30.04$ & $38.4 \pm 8.13$ & 4.70 \\
\hline \multirow[t]{4}{*}{ A. lamellicauda:A. pelewensis } & $39: 1$ & $\mathrm{R} 8 \mathrm{e} 4$ & 2.83 & 40 & $5.1 \pm 0.75$ & 3.5 & 7.0 & $126.0 \pm 38.25$ & $36.0 \pm 10.38$ & 2.11 \\
\hline & $53: 1$ & R11e3 & 2.08 & 54 & $5.2 \pm 0.87$ & 3.2 & 6.2 & $130.9 \pm 47.59$ & $37.1 \pm 12.70$ & 2.84 \\
\hline & $29: 11$ & R9e5 & 2.80 & 40 & $2.8 \pm 0.93$ & 3.5 & 12.7 & $34.6 \pm 28.09$ & $9.9 \pm 8.41$ & 2.41 \\
\hline & $55: 10$ & R11e4 & 2.08 & 65 & $2.9 \pm 0.77$ & 3.0 & 10.3 & $33.8 \pm 23.03$ & $9.9 \pm 6.93$ & 0.93 \\
\hline $\begin{array}{l}\text { A. lamellicauda:Doxomysis } \\
\text { littoralis }\end{array}$ & $46: 1$ & R8e3 & 2.75 & 47 & $5.0 \pm 0.62$ & 3.4 & 6.7 & $123.9 \pm 32.62$ & $35.4 \pm 8.91$ & 3.60 \\
\hline $\begin{array}{l}\text { A. lamellicauda:Prionomysis } \\
\text { stenolepis }\end{array}$ & $46: 1$ & R3e5 & 2.00 & 47 & $5.3 \pm 0.64$ & 3.4 & 6.3 & $140.1 \pm 30.04$ & $39.9 \pm 8.22$ & 5.16 \\
\hline
\end{tabular}

Estimates of secondary production and food requirements

Annual productivity and consumption patterns mirrored the distribution and abundance of the more ubiquitous species. The 3 dominant mysid species Erythrops nana, Anisomysis pelewensis, and Doxomysis littoralis were most abundant from September through December (Fig. 3). Catches among replicates were generally uniform (small standard errors), with the exception of March when large numbers of A. australis $\left(3207.8 \mathrm{~m}^{-3}\right)$ were present in only 1 of 3 replicate samples. This species forms large, patchily distributed shoals and is generally not sampled effectively by the benthic sampler (Carleton \& Hamner 1989). The numerical dominance on that occasion by this relatively large mysid $(\bar{x}=2.5 \mathrm{~mm})$ distorted seasonal estimates of biomass, productivity, and consumption, as did the presence of a large number of mature females of A. laticauda in July (Fig. 3). As A. australis is poorly sampled by the benthic sampler, this species was excluded from computation of annual values. Biomass, productivity, and consumption estimates in September and October reflected the distribution and abundance of the smaller, but dominant species ( $E$. nana, $2.3 \mathrm{~mm}$; A. pelewensis, $2.1 \mathrm{~mm}$ ), while estimates for December reflected the additional presence of the large species D. littoralis $(3.2 \mathrm{~mm})$. The small number of Prionomysis stenolepis had a disproportionate impact on estimates because of their large size $(3.7 \mathrm{~mm})$.

\section{DISCUSSION}

The role of the hyperbenthos in various marine ecosystems is poorly understood. It has been suggested that this community plays an important part in the coupling of benthic and pelagic food webs through daily vertical migrations; although, for most hyperbenthic taxa, insufficient data are available for the study of energy fluxes (Mees \& Jones 1997). In the present study we addressed some of these shortcomings for coral reef lagoon mysids, an important component of the lagoon hyperbenthic community (Carleton \& Hamner 2007). Prior to this investigation, functional relationships between length, chemical composition, and 

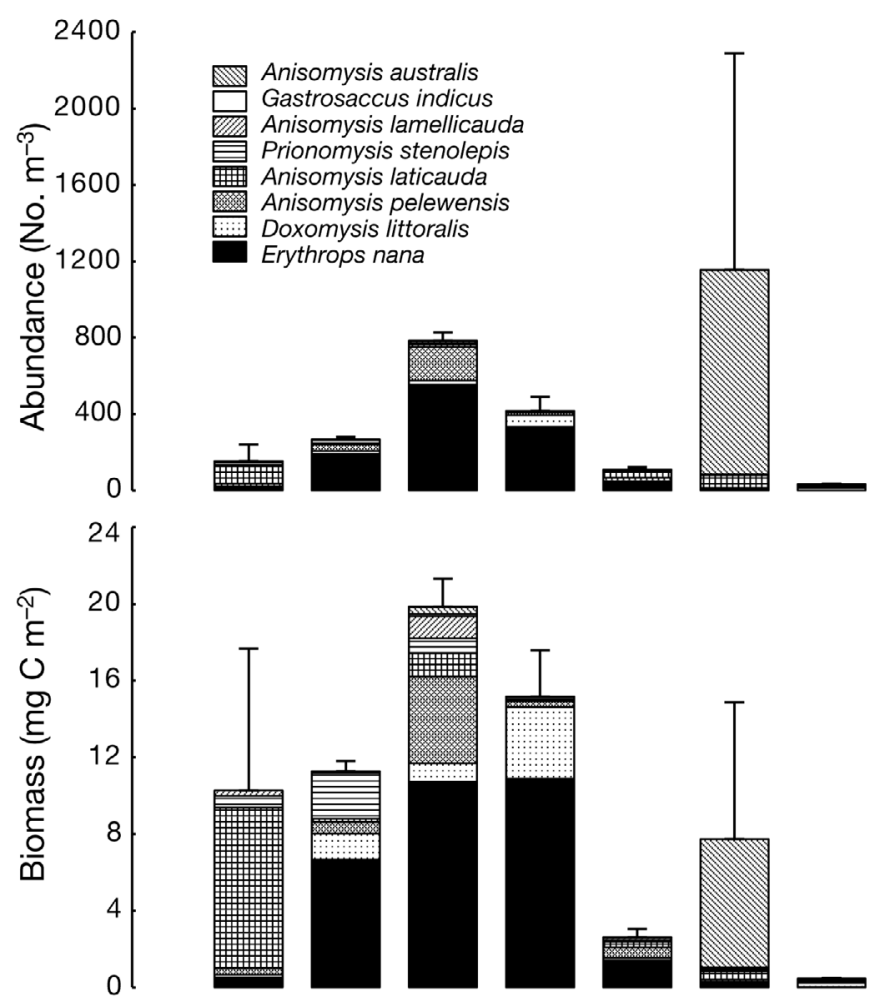

from September to December (Fig. 3), which mirrors the seasonal distribution and availability of particulate nutrients and not that of in situ primary production, suggesting that detritus must play a major role in sustaining a large portion of the lagoon mysid community.

The mean production rate for lagoon mysids, excluding the shoaling species Anisomysis australis, was $2.8 \mathrm{mg} \mathrm{C} \mathrm{m}^{-3}$ $\mathrm{d}^{-1}$ and ranged from $0.19 \mathrm{mg} \mathrm{C} \mathrm{m}^{-3} \mathrm{~d}^{-1}$ in May to $6.5 \mathrm{mg} \mathrm{C} \mathrm{m}^{-3} \mathrm{~d}^{-1}$ in October and accounted for 1 to $21 \%$ of the detritus deposition as measured by Hansen et al. (1992) at shallow lagoon sites (Table 2). These levels of detrital consumption are low when compared to those of the sediment infaunal and bacterial communities. The sediment infaunal community of large polychaetes, crustaceans, bivalves, and gastropods consumes from 28 to $76 \%$ of total carbon from both detritus deposition and gross primary production (Riddle et al. 1990), while the sediment bac-

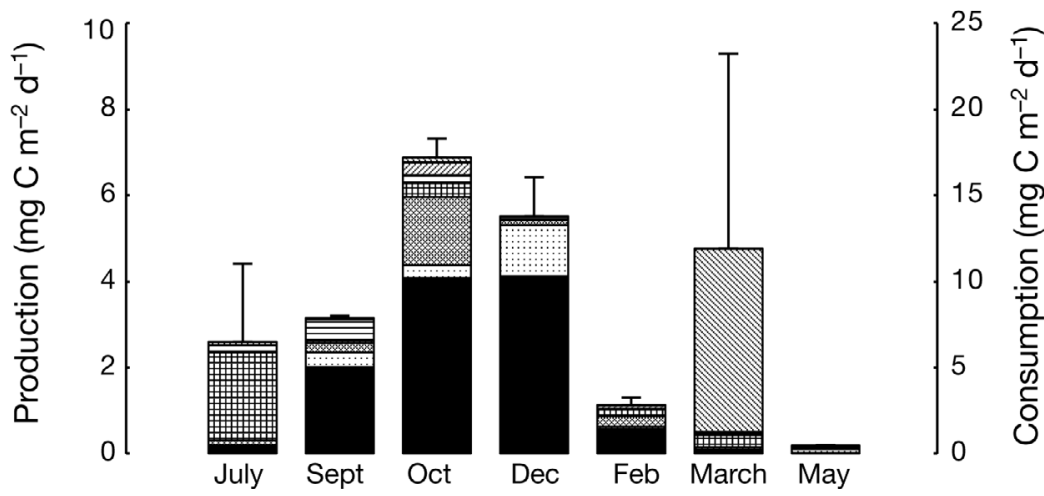

Fig. 3. Monthly abundance, biomass, and secondary production/consumption $( \pm \mathrm{SE})$ for the lagoon mysid community

respiration, and estimates of secondary production and feeding were not available for these reef-resident taxa.

Most lagoon mysids are detritivores. This is evident from their gut contents (>90\% of specimens contained amorphous material in their foregut) and is supported by their seasonal distribution patterns. Hansen et al. (1992) measured detritus deposition, benthic community metabolism, and bacterial production in Davies Reef lagoon on 4 occasions throughout 1986 (February, May, August, and October) and found the highest deposition rate of particulate matter in October (Table 2). However, benthic gross primary production rates were significantly higher in February and May. Lagoon mysids were most abundant during austral spring and early summer ratio of 3.2 (Hansen et al. 1992). This shift in the $\mathrm{C}: \mathrm{N}$ ratio is most likely due to the utilization of the more labile carbon compounds by the various water column, lagoon floor, and sediment communities as detrital material settles out. Ultimately, however, all unassimilated detrital material and waste from the lagoon floor and macro-infaunal communities is respired or recycled by sediment microbes (Alongi 1998).

Although mysids process less detritus than infaunal invertebrates or bacteria, they do consume a similar quantity to the water column zooplankton. Roman et al. (1990) determined that approximately $77 \%$ of the particulate carbon in the lagoon water column at Davies Reef was detritus and that a further $7 \%$ was composed of phytoplankton $>2 \mu \mathrm{m}$ and thus available to the small, 
Table 2. Comparison of biomass $\left(\mathrm{mg} \mathrm{C} \mathrm{m}^{-2}\right)$, daily production and consumption $\left(\mathrm{mg} \mathrm{C} \mathrm{m}^{-2} \mathrm{~d}^{-1}\right)$ of mysid community with sediment bacterial and macro-infaunal communities over 4 mo in Davies Reef lagoon in relation to rates $\left(\mathrm{mg} \mathrm{C} \mathrm{m}^{-2} \mathrm{~d}^{-1}\right)$ of detrital deposition and gross primary production

\begin{tabular}{|c|c|c|c|c|c|c|c|c|c|c|c|c|c|c|}
\hline \multirow[t]{4}{*}{ Month } & \multicolumn{6}{|c|}{ Hansen et al. (1992) } & \multirow{2}{*}{\multicolumn{4}{|c|}{$\begin{array}{l}- \text { Riddle et al. (1990) }- \\
\text { _ Sediment macro-infauna }\end{array}$}} & \multicolumn{4}{|c|}{ - Present study } \\
\hline & \multirow{3}{*}{$\begin{array}{c}\text { Detritus } \\
\text { deposition }\end{array}$} & \multirow{3}{*}{$\begin{array}{c}\text { Gross } \\
\text { primary } \\
\text { production }\end{array}$} & \multirow{3}{*}{$\begin{array}{l}\text { Total } \\
\text { carbon } \\
\text { input }\end{array}$} & \multicolumn{3}{|c|}{ — Sediment bacteria - } & & & & & - & Mysid comm & nunity - & 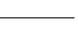 \\
\hline & & & & Production & Cons & umption & Biomass & Production & Cons & nption & Biomass & Production & Consu & mption \\
\hline & & & & & Rate & $\begin{array}{l}\% \text { Total } \\
\text { carbon }\end{array}$ & & & Rate & $\begin{array}{l}\text { Total } \\
\text { arbon }\end{array}$ & & & Rate & $\begin{array}{l}\% \\
\% \\
\text { etritus }\end{array}$ \\
\hline Jul & 69 & 98 & 167 & 81 & 162 & 97 & 2048 & 23.9 & 127 & 76 & 10.0 & 2.52 & 6.30 & 9 \\
\hline Sep & & & & & & & & & & & 11.2 & 3.13 & 7.81 & \\
\hline Oct & 78 & 89 & 239 & 240 & 480 & 201 & 2810 & 25.3 & 140 & 59 & 18.3 & 6.50 & 16.25 & 21 \\
\hline Dec & & & & & & & & & & & 15.2 & 5.51 & 13.78 & \\
\hline Feb & 16 & 373 & 389 & 105 & 210 & 54 & 3405 & 27.5 & 156 & 40 & 2.5 & 1.05 & 2.64 & 17 \\
\hline Mar & & & & & & & & & & & 1.0 & 0.49 & 1.22 & \\
\hline May & 58 & 365 & 423 & 121 & 242 & 57 & 2762 & 22.2 & 120 & 28 & 0.5 & 0.19 & 0.47 & 0.82 \\
\hline
\end{tabular}

particle-grazing copepods that dominated their samples. At an average detritus concentration of $89 \mu \mathrm{g} \mathrm{Cl}^{-1}$ and phytoplankton biomass of $8 \mu \mathrm{g} \mathrm{Cl}^{-1}$, an individual copepod could ingest $178 \mu \mathrm{g} \mathrm{C} \mathrm{mg}{ }^{-1} \mathrm{C} \mathrm{h}^{-1}$ of detritus and $72 \mu \mathrm{g} \mathrm{C} \mathrm{mg}{ }^{-1} \mathrm{C} \mathrm{h}^{-1}$ of phytoplankton. When applied to mean diurnal biomass in the water column for August, these ingestion rates equate to $3.7 \mathrm{mg} \mathrm{C}$ $\mathrm{m}^{-3} \mathrm{~d}^{-1}$ of detritus and $1.5 \mathrm{mg} \mathrm{C} \mathrm{m}^{-3} \mathrm{~d}^{-1}$ of phytoplankton. The diurnal feeding rate for the lagoon floor mysid community, excluding Anisomysis australis, was $6.3 \mathrm{mg} \mathrm{C} \mathrm{m}^{-3} \mathrm{~d}^{-1}$ for July and $7.8 \mathrm{mg} \mathrm{C} \mathrm{m}^{-3} \mathrm{~d}^{-1}$ for September, with an average for this period of $7.1 \mathrm{mg}$ $\mathrm{C} \mathrm{m}^{-3} \mathrm{~d}^{-1}$, a rate greater than the consumption during August of both phytoplankton and detritus by the entire water column community $\left(5.3 \mathrm{mg} \mathrm{C} \mathrm{m}^{-3} \mathrm{~d}^{-1}\right.$ ).

Lagoon mysids are relatively unimportant as prey to both diurnal and many nocturnal planktivorous fish (Hobson \& Chess 1978). By day, mysid schools in Davies Reef lagoon stayed well clear of coral outcrops housing planktivorous damselfish and high enough above the substrate to avoid capture by benthic gobies (Carleton \& Hamner 1989). At night, predation by cardinal fish may account for the loss of smaller individuals (Hobson \& Chess 1978), although few fish were observed during night dives at the study site. This observation is not exceptional as the concentrations of planktivores in the still waters of reef lagoons are generally less than in more turbulent areas such as the reef front (Hamner et al. 1988). Unlike resident demersal plankton (see Jacoby \& Greenwood 1988 for review) or hyperbenthic species in other ecosystems (Mees \& Jones 1997), lagoon mysids do not undertake extensive nocturnal migrations into the water column, but remained concentrated on or near the substratum (Carleton \& Hamner 1989). Of the more abundant resident species, only Anisomysis laticauda was consistently captured on the lagoon floor by day and in the surface waters at night (Carleton \& Hamner 1989) and may thus play a part in the tight benthic-pelagic coupling prevalent on coral reefs (Alongi 1998). The mean nocturnal abundance of this species in lagoon surface waters was only 5.5 ind. $\mathrm{m}^{-3}$, but due to their relatively large size, this represents a potential loss of mysid production ranging from $0.4 \%$ in October to $22 \%$ in May that is either consumed by nocturnal, sessile planktivores or flushed from the lagoon by wind-driven surface currents.

The majority of studies into the trophodynamic role of mysids within various ecosystems has focused primarily on cold-water, temperate species from coastal, deep-ocean, and freshwater habitats. To directly compare secondary production in tropical, coral reef species with those from colder climates is difficult as estimates of productivity are determined by various methods (Omori \& Ikeda 1984), are a function of parameters that differ greatly (temperature, size of individuals, standing stock, life histories, etc.), and results are reported in a variety of units. There are, however, several studies on species from warmer habitats that enable direct comparisons with the results from the present study (Table 3). Average daily production of Anisomysis pelewensis in Davies Reef lagoon, when converted to micrograms dry weight per mysid per day (assuming $40 \%$ of dry weight is carbon), was almost twice as high as for the same species in Shijiki Bay, southern Japan (Morioka et al. 1987), where respiration measurements were taken at $20^{\circ} \mathrm{C}, 8.8^{\circ} \mathrm{C}$ cooler than present experiments. Though their specimens of A. pelewensis were on average larger, consumption estimates at the 2 locations were very similar. However, their measurements on the feeding rates of Mysidopsis surugae, a much larger animal than any in Davies Reef lagoon, were considerably higher, and only the estimates for the larger lagoon species Prionomysis stenolepis, Gastrosaccus indicus, and A. australis approached a comparable rate. Mullin \& Roman 

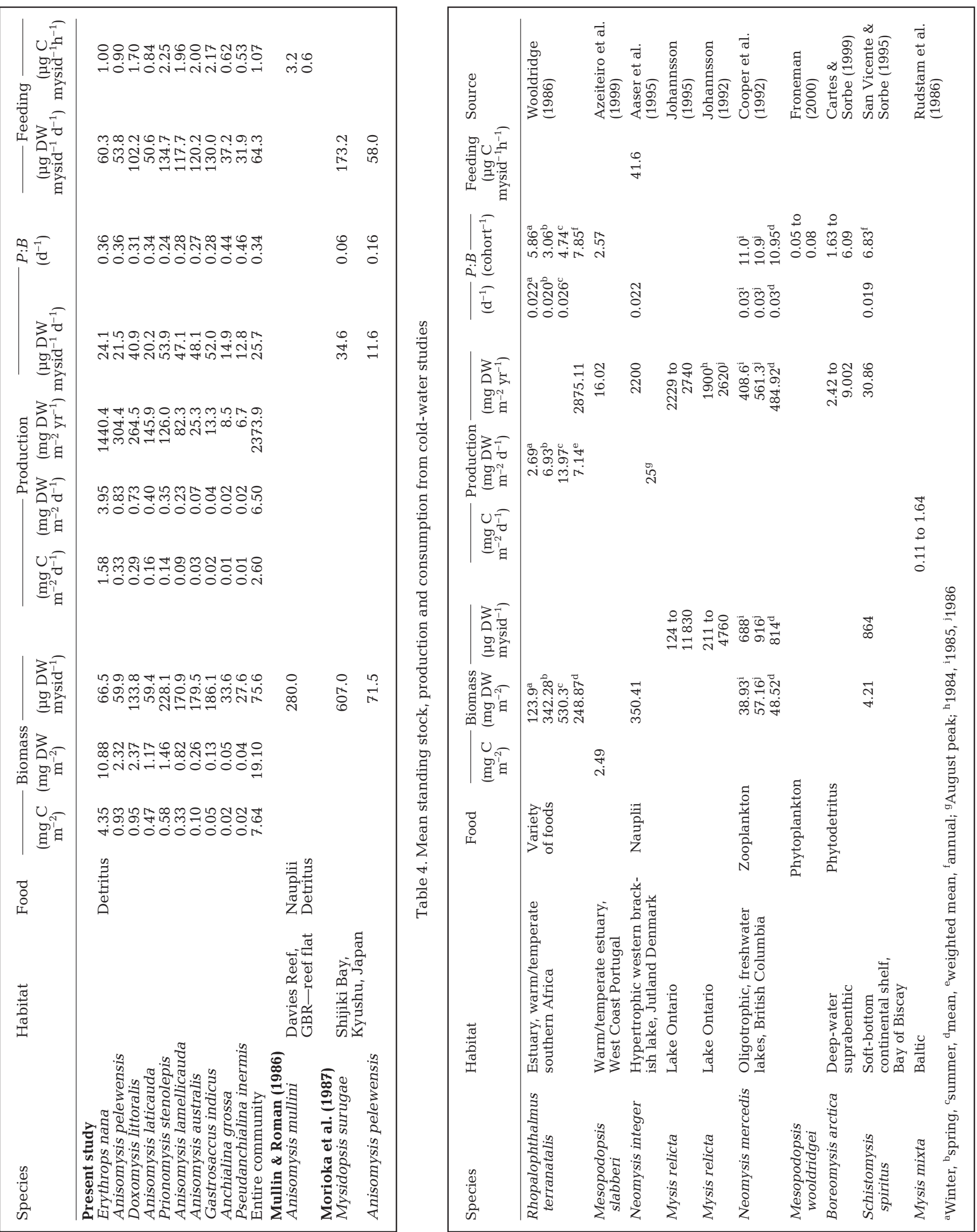
(1986) obtained generally lower feeding rates than our estimates for lagoon mysids when $A$. mullini, a species which forms diurnal swarms on the reef flat at Davies Reef, was fed in situ on radioactively labeled coral mucus and detritus (Table 3). When fed Artemia, an unnatural food, consumption rates were higher than for any lagoon species.

Estimates of daily and yearly production for individual coral reef lagoon species were either comparable or very much lower than estimates for cold-water, temperate species (Table 4). All of the species listed in Table 4 are considerably larger than the tropical species in the present study, are generally long-lived, have a much higher standing stock, and often form a mono-specific mysid community (e.g. Mysis relicta in Lake Ontario). These factors all contribute to high estimates of production. Only when the productivity of the entire mysid community is considered do present estimates approximate those of the colder water species. However, daily $P: B$ ratios for Davies Reef lagoon mysids are extremely high in comparison with the daily ratios for cold-water species (Table 4). Lagoon species are small and have low standing stocks, but their high turnover rates result in high estimates of annual production.

Secondary production rates presented in this study are based primarily on data from Anisomysis lamellicauda and A. pelewensis. Nonetheless, we believe our estimates for the entire hyperbenthic mysid community are realistic first approximations, albeit somewhat conservative. A. lamellicauda and A. pelewensis form a ubiquitous component of the mysid community (Carleton \& Hamner 1989), and the size range of specimens utilized for oxygen consumption experiments encompassed the length of $>80 \%$ of all mysids sampled throughout 1980/1981. Ikeda (1985) estimated that approximately $95 \%$ of the variation in oxygen consumption rates for zooplankton could be attributed to habitat temperature and body size. By factoring seasonal changes in habitat temperature into our calculations and by utilizing a wide size range of mysids, these important sources of variation have been addressed. However, our estimates must be considered as conservative. Respiration measurements were made on animals in a resting state, confined within relatively small-volume respirometers, which may result in readings 1.5 to 2 times lower than those for actively swimming animals (Shushkina 1972). Also, A. australis, a poorly sampled shoaling species, was excluded from community productivity calculations (Table 2). This species forms large, patchily distributed shoals of variable length, width, and depth that actively course across the lagoon floor (Carleton \& Hamner 1989). This species is probably more abundant than suggested by present sampling techniques, and as they form and maintain large, mobile shoals, most likely have respiration rates much higher than those measured in this study (Buskey 1998).

In most marine ecosystems there is an increase in biomass at the benthic boundary layer relative to the overlying water column, yet this zone and its fauna remain relatively poorly studied (Mees \& Jones 1997). Large areas of Indo-Pacific coral reefs and atolls are either sandy lagoons or back-reef slopes that harbor a rich diversity of hyperbenthic fauna. Our estimates of mysid production, albeit for only 1 component of this community, highlight the importance of the hyperbenthos and are a first step toward a better understanding of the role of this community within the broader coral reef ecosystem. To fully account for carbon flow within coral reef ecosystems, we need more and better estimates of the abundance, composition, and metabolism of the entire hyperbenthic community.

Acknowledgements. We thank T. Ikeda for inspiration and encouragement; S. Boyle for chemical analysis of specimens; I. Bush, S. Davies, and M. Temby for their valuable assistance with reference material; and the crew of the RV 'Lady Basten' for their support at sea.

\section{LITERATURE CITED}

Aaser HF, Jeppesen E, Søndergaard M (1995) Seasonal dynamics of the mysid Neomysis integer and its predation on the copepod Eurytemora affinis in a shallow hypertrophic brackish lake. Mar Ecol Prog Ser 127:47-56

Alongi DM (1986) Population structure and trophic composition of the free-living nematodes inhabiting carbonate sands of Davies Reef, Great Barrier Reef, Australia. Aust J Mar Freshw Res 37:609-619

Alongi DM (1988) Detritus in coral reef ecosystems: fluxes and fates. In: Choat JH, et al (eds) Proc 6th Int Coral Reef Symp, Vol 2.Coral Reef Symposium Executive Committee, Townsville, p 29-36

Alongi DM (1998) Coastal ecosystem processes. CRC Press, Boca Raton, FL

Azeiteiro UMM, Jesus L, Marques JC (1999) Distribution, population dynamics, and production of the suprabenthic mysid Mesopodopsis slabberi in the Mondego Estuary, Portugal. J Crustac Biol 19:498-509

Birkett L, Mclntyre AD (1971) Treatment and sorting of samples: In: Holme NA, Mclntyre AD (eds) Methods for the study of marine benthos. Blackwell, Oxford, p 156-168

Buskey EJ (1998) Energetic cost of position-holding behavior in the planktonic mysid Mysidium columbiae. Mar Ecol Prog Ser 172:139-147

Carleton JH, Hamner WM (1987) A diver operated device for the capture of mobile epibenthic organisms. Limnol Oceanogr 32:503-510

Carleton JH, Hamner WM (1989) Resident mysids: community structure, abundance and small-scale distributions in a coral reef lagoon. Mar Biol 102:461-472

Carleton JH, Hamner WM (2007) The hyperbenthic plankton community: composition, distribution, and abundance in a coral reef lagoon. Mar Ecol Prog Ser 336:77-88

Cartes JE, Maynou F (2001) Trophodynamics of the deep-water 
suprabenthic mysid Boreomysis arctica in the Catalan Sea (western Mediterranean). Mar Ecol Prog Ser 211:225-234

Cartes JE, Sorbe JC (1999) Estimating secondary production in bathyal suprabenthic peracarid crustaceans from the Catalan Sea slope (western Mediterranean; 391-1255 m). J Exp Mar Biol Ecol 239:195-210

Clutter RI, Theilacker GH (1971) Ecological efficiency of a pelagic mysid shrimp; estimates from growth, energy budget, and mortality studies. Fish Bull 69:93-115

Cooper KL, Hyatt KD, Rankin DP (1992) Life history and production of Neomysis mercedis in two British Columbia coastal lakes. Hydrobiologia 230:9-30

Emery AR (1968) Preliminary observations on coral reef plankton. Limnol Oceanogr 13:293-303

Froneman PW (2000) Feeding studies on selected zooplankton in a temperate estuary, South Africa. Estuar Coast Shelf Sci 51:543-552

Gottfried M, Roman MR (1983) Ingestion and incorporation of coral-mucus detritus by reef zooplankton. Mar Biol 72: 211-218

Hamner WM, Jones MS, Carleton JH, Hauri IR, Williams DMcB (1988) Zooplankton, planktivorous fish and water currents on a windward reef face: Great Barrier Reef, Australia. Bull Mar Sci 42:459-479

Hansen JA, Klumpp DW, Alongi DM, Dayton PK, Riddle MJ (1992) Detrital pathways in a coral reef lagoon. II. Detritus deposition, benthic microbial biomass and production. Mar Biol 113:363-372

Hobson ES, Chess JR (1978) Trophic relationships among fishes and plankton in the lagoon at Enewetak Atoll, Marshall Islands. Fish Bull 76:133-153

Ikeda T (1985) Metabolic rates of epipelagic marine zooplankton as a function of body mass and temperature. Mar Biol 85:1-11

Ikeda T, Motoda S (1978) Estimated zooplankton production and their ammonia excretion in the Kuroshio and adjacent seas. Fish Bull 76:357-367

Ikeda T, Carleton JH, Mitchell AW, Dixon P (1982) Ammonia and phosphate excretion by zooplankton from the inshore waters of the Great Barrier Reef. II. Their in situ contributions to nutrient regeneration. Aust J Mar Freshw Res 33: 683-698

Iversen TM, Dall P (1989) The effect of growth pattern, sampling interval and number of size classes on benthic invertebrate production estimated by the size-frequency method. Freshw Biol 22:323-331

Jacoby CA, Greenwood JG (1988) Spatial, temporal and behavioral patterns in emergence of zooplankton in the lagoon of Heron Reef, Great Barrier Reef, Australia. Mar Biol 97:309-328

Johannsson OE (1992) Life history and productivity of Mysis

Editorial responsibility: Otto Kinne (Editor-in-Chief), Oldendorf/Luhe, Germany relicta in Lake Ontario. J Great Lakes Res 18:154-168

Johannsson OE (1995) Response of Mysis relicta population dynamics and productivity to spatial and seasonal gradients in Lake Ontario. Can J Fish Aquat Sci 52:1509-1522

Lasenby DC, Langford RR (1973) Feeding and assimilation of Mysis relista. Limnol Oceanogr 18:280-285

Mauchline J (1980) The biology of mysids. Adv Mar Biol 18: $1-369$

Mees J, Jones MB (1997) The hyperbenthos. Oceanogr Mar Biol Annu Rev 35:221-255

Morioka Y, Nakashima J, Kimoto K (1987) Oxygen consumption and biological productivity of mysid population in a small inlet of Kyushu. Bull Seikai Reg Fish Res Lab 65: 115-123

Mullin MM, Roman MR (1986) In situ feeding of a schooling mysid, Anisomysis sp., on Davies Reef-MECOR 4. Bull Mar Sci 39:623-629

Omori M, Ikeda T (1984) Methods in marine zooplankton ecology. John Wiley \& Sons, New York

Riddle MJ, Alongi DM, Dayton PK, Hansen JA, Klumpp DW (1990) Detrital pathways in a coral reef lagoon. I. Macrofaunal biomass and estimates of production. Mar Biol 104: 109-118

Roman MR, Furnas MJ, Mullin MM (1990) Zooplankton abundance and grazing at Davies Reef, Great Barrier Reef, Australia. Mar Biol 105:73-82

Rudstam LG, Hansson S, Larsson U (1986) Abundance, species composition and production of mysid shrimps in a coastal area of the northern Baltic proper. Ophelis Suppl 4: $225-238$

San Vicente C, Sorbe JC (1995) Biology of the suprabenthic mysid Schistomysis spiritus (Norman, 1860) in the southeastern part of the Bay of Biscay. Sci Mar 59(Suppl 1): 71-86

Shushkina EA (1972) Intensity of production and utilization of assimilated food for growth of mysids from the Sea of Japan. Oceanology 12:275-285

Toda H, Arima T, Takahashi M, Ichimura S (1987) Physiological evaluation of temperature effect on the growth processes of the mysid, Neomysis intermedia Czerniawsky. J Plankton Res 9:51-63

Van Guelpen L, Markle DE, Duggan DJ (1982) An evaluation of accuracy, precision, and speed of several zooplankton subsampling techniques. J Cons Int Explor Mer 40: 226-236

Wilkinson CR (1987) Microbial ecology on a coral reef. Search 18:31-33

Wooldridge TH (1986) Distribution, population dynamics and estimates of production for the estuarine mysid, Rhopalophthalmus terranatalis. Estuar Coast Shelf Sci 23: 205-223

Submitted: May 25, 2006; Accepted: September 28, 2006

Proofs received from author(s): March 29, 2007 